\title{
KAJ MENIJO BRALCI O REVIJI ANDRAGOŠKA SPOZNANJA
}

$V_{\mathrm{p}}$

prejšnji številki revije Andragoška spoznanja je bila objavljena anketa, s katero so bralci ocenjevali svojo revijo.

Namen ankete je bil ugotoviti ustreznost vsebine in oblike revije ter izvedeti nekaj več o strukturi naših bralcev. Prav tako smo želeli izvedeti, katere članke bralci najraje prebirajo, in obenem dobiti čim več informacij o željah in pričakovanjih bralcev in tako prihodnje številke revije narediti še zanimivejše.

Vsem, ki ste nam anketo z odgovori vrnili, se lepo zahvaljujemo in hkrati sporočamo, da bomo na ta način $\mathrm{v}$ uredništvu zbrane ideje, zamisli, komentarje in kritike skušali čim bolj upoštevati.

Do konca decembra 1998 smo prejeli 58 izpolnjenih vprašalnikov. $\mathrm{V}$ nadaljevanju tega prispevka predstavljamo najpomembnejše ugotovitve in najzanimivejše komentarje.

\section{KDO BERE REVIJO ANDRAGOŠKA SPOZNANIA}

$\mathrm{V}$ anketi nas je najprej zanimalo, kdo bere revijo Andragoška spoznanja in kaj bi lahko še storili, da bi izboljšali njeno vsebino in podobo.

Revijo Andragoška spoznanja v četrtem letu njenega izhajanja berejo malodane $\mathrm{v}$ vseh strukturah slovenskega gospodarstva in negospodarstva. Njeni naročniki so podjetja, nevladne organizacije in tudi posamezniki. $\mathrm{V}$ tabeli je prikazana struktura naročnikov.

\begin{tabular}{|c|c|}
\hline \multicolumn{2}{|c|}{ Naročniki revije Andragoskka spoznanja } \\
\hline Oiganizocie: & Deležn narónililovy $\%$ \\
\hline podjetio & 38 \\
\hline laobroževeline organizocie & 27 \\
\hline knizizice & 8 \\
\hline Organizecie skinpol: & 73 \\
\hline \multicolumn{2}{|l|}{ Posamezilik: } \\
\hline Sudente & 21 \\
\hline zaposeni & 4,5 \\
\hline upokjejenci & 1,5 \\
\hline 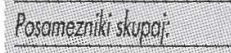 & 27 \\
\hline
\end{tabular}

Med organizacijami nas je še zlasti zanimalo, kakšna je struktura izobraževalnih organizacij.

\begin{tabular}{|c|c|c|}
\hline \multicolumn{3}{|c|}{ Strukura izobroževal hih organizoci - noročnikov Andragoskikh spoznan } \\
\hline Vrsta izobraževalne organizacije & \% noročntikov & $\begin{array}{l}\text { \% vseh izodr. } \\
\text { organizoci" }\end{array}$ \\
\hline Zasebne in joune izobrozievalne organizocije & 14 & 95 \\
\hline Univerze in viseke strokoune sole & 5 & 3,4 \\
\hline Sredile Sole & 6 & 39 \\
\hline Osnomesole & 1,7 & 12 \\
\hline Duge izobroževalne organizocie & 0,3 & 0.4 \\
\hline Sloupei & 27 & 18.4 \\
\hline 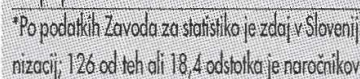 & 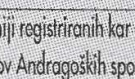 & obrcżevalinhioggo \\
\hline
\end{tabular}

\section{STRUKTURA BRALCEV}

$\mathrm{V}$ anketi smo želeli izvedeti še več o tem, kdo prebira prvo slovensko revijo za izobraževanje odraslih. Tako smo bralce vprašali po starosti, spolu in stopnji izobrazbe. Med tistimi, ki so vrnili anketni vprašalnik, prevladuje starost od 40 do 55 let (33 odstotkov bralcev), druga najmočnejša starostna skupina so bralci, stari od 20 do 26 let (skoraj 28 odstotkov bralcev); 22 odstotkov jih je starih od 30 do 40 let in 11 odstotkov nad 55 let.

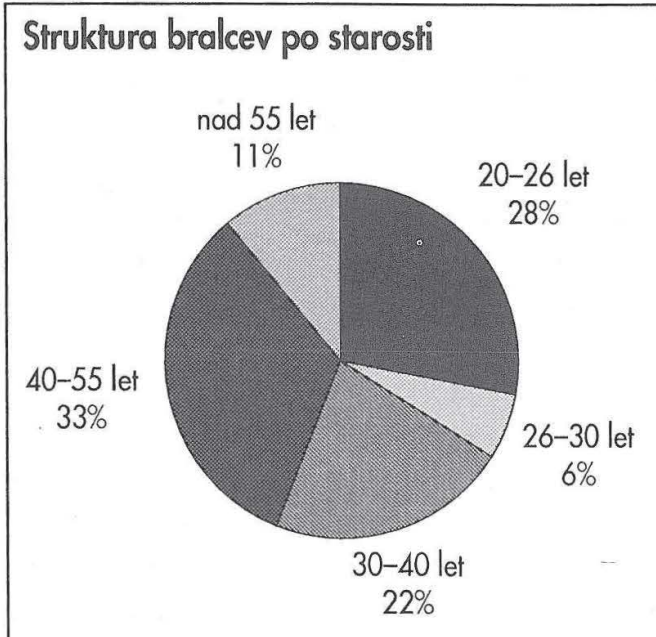

Zanimivo je da med bralci revije zelo prednjačijo ženske; anketo je izpolnilo kar 83 
odstotkov bralk, bralcev pa le 17 odstotkov. Največ, kar 55,5 odstotka bralcev ima končano fakulteto, 11 odstotkov pa višjo šolo. Med bralci je tudi zelo visok odstotek tistih $\mathrm{z}$ akademskimi nazivi, magisterij ali doktorat ima kar 22 odstotkov bralcev. Tudi odstotek tistih, ki so končali srednjo šolo, je dokaj visok, kar 16,6 odstotka. To so predvsem študenti Univerze v Ljubljani in Mariboru.

\section{KAJ BRALCI NAIRAJE BEREJO}

Pri tem nas je zanimalo dvoje: koliko člankov $\mathrm{v}$ reviji bralci preberejo in katere vsebine jih najbolj pritegnejo.

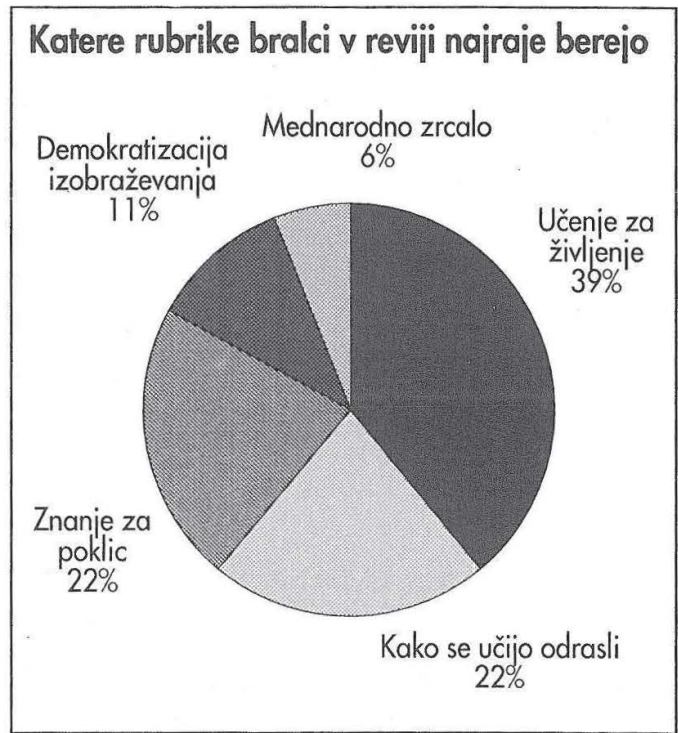

Kar 34 odstotkov bralcev ponavadi prebere vse članke v reviji, približno polovico člankov ali nekaj več jih prebere 50 odstotkov bralcev, manj kot polovico pa 16 odstotkov.

Najbolj priljubljeni so članki o učenju za življenje - torej splošnoizobraževalne teme o učenju odraslih, za katere je glasovalo kar 39 odstotkov bralcev, rubrika Kako se učijo odrasli je dobila 22 odstotkov zmagovalnih glasov, prav tako članki v rubriki znanje za poklic. Teme o demokratizaciji izobraževanja je med svoje najljubše uvrstilo 11 odstotkov bralcev, Mednarodno zrcalo oziroma prispevke tujih avtorjev pa najraje prebira 6 odstotkov vprašanih. Med najmanj branimi pa so zgodovinske teme s področja izobraževanja odraslih.

\section{KAJ BRALCI V REVIJI POGREŠAJO}

Naši bralci želijo, da bi bilo v prihodnjih številkah revije več tem s teh področij:

* izobraževanje v podjetjih,

* predstavitev izobraževalnih dejavnosti uspešnih slovenskih podjetij

* dileme in novosti poklicnega in strokovnega izobraževanja odraslih

* marketing v izobraževanju odraslih

* didaktične in metodološke vsebine

* raziskave izobraževalnih potreb

* andragoško svetovanje

* andragoško izrazoslovje

* ponudbe izobraževanja odraslih

* predstavitev novih izobraževalnih programov

* ocene in polemike

* prihodnost izobraževanja odraslih

Predvsem pa večina sodelujočih $\mathrm{v}$ raziskavi želi še več konkretnih tem, tem iz prakse, s pomočjo katerih bi lahko takoj izboljšali svojo lastno prakso.

\section{INFORMATIVNA VREDNOST REVIJE}

Namen vsake revije je informirati javnost o dogodkih, trendih in pojavih na določenem področju. Tako smo tudi našim bralcem zastavili vprašanje, ali menijo, da so z naročilom revije bolj seznanjeni z dogajanji na področju izobraževanja odraslih. Vsi vprašani so odgovorili pritrdilno. Omenimo pa še, da je kar 72 odstotkov bralcev uporabnikov interneta in da bi bilo torej $\mathrm{v}$ prihodnosti smiselno razmišljati tudi o elektronski obliki revije.

\section{KAKO SO BRALCI OCENILI REVIJO ANDRAGOŠKA SPOZNANJA}

Najprej nas je zanimalo, kaj bralci menijo o dolžini oziroma obsegu člankov v reviji. Bralci, sodelujoči v raziskavi, v večini (94 odstotkov) menijo, da so članki ravno prav obsežni, preostali ( 6 odstotkov) pa, da so preobsežni.

Bralce smo poprosili tudi, naj revijo ocenijo $\mathrm{z}$ 
ocenami od 1 do 5 ( 5 odlično, 1 slabo), in sicer so posebej ocenili vsebino, grafično podobo in revijo kot celoto.

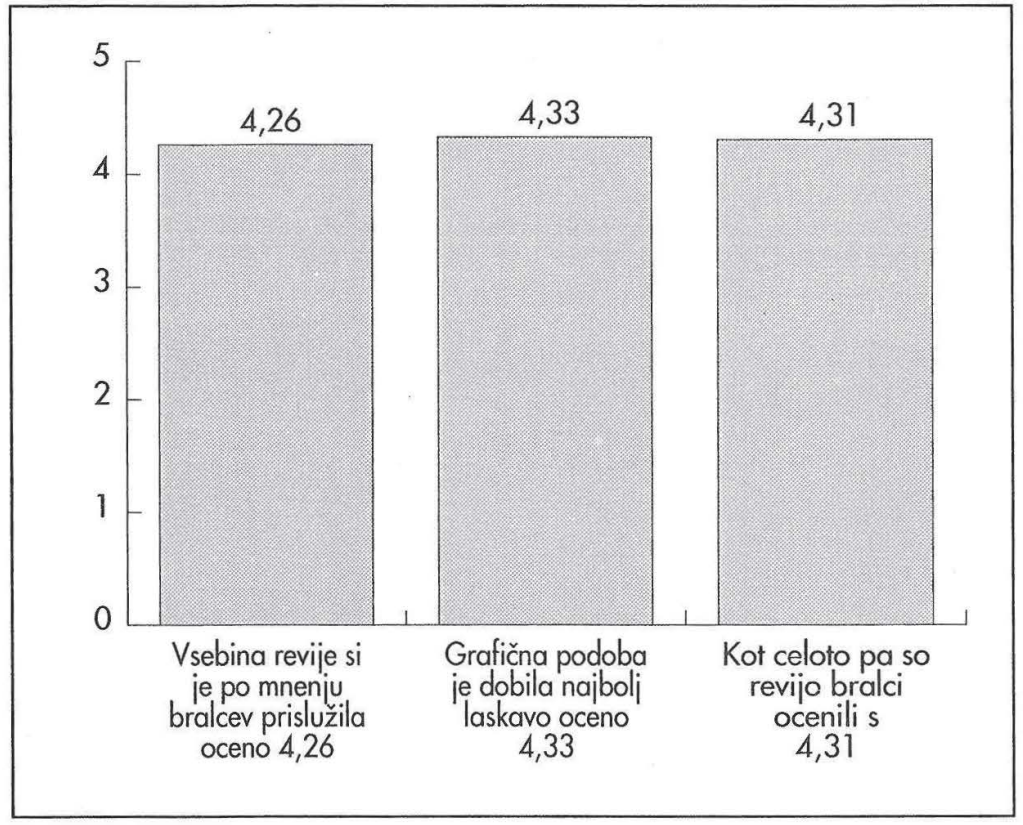

KAJ SO ŠE POVEDALI

NAŠI BRALCI

Nekdo izmed bralcev meni, da ima revija lep papir. Veliko sodelujočih $\mathrm{v}$ raziskavi nam je prijazno zaupalo, da takšno revijo resnično potrebujemo, in nam želi uspešno delo še naprej. Večino bralcev pa moti predvsem to, da revija izhaja le štirikrat na leto.

\section{ŠE BESEDA UREDNIŠTVA}

Tudi v uredništvu se pridružujemo večinskemu mnenju naših bralcev. Radi bi, da bi revija izhajala pogosteje, saj menimo, da je postala osrednji znanstveno-strokovni tiskani medij na tem področju in je kot taka nepogrešljiva za razvoj andragoške in tudi pedagoške stroke v Sloveniji. Toda dokler revija ne bo ujela pozitivnih finančnih tokov, bomo v uredništvu prisiljeni krojiti omejeno uredniško politiko. Vendarle pa z optimizmom gledamo $\mathrm{v}$ prihodnost in se skupaj z vami že vnaprej veselimo dneva, ko bomo lahko napovedali pogostejše izhajanje revije Andragoška spoznanja.
Pripravila:

mag. Daniela Brečko, 